International Journal of Research in Indian Medicine

\title{
Stress and constipation (vibandha) - critical review
}

Dipashri Eknath Borse ${ }^{* 1}$, Santosh Chavhan ${ }^{2}$

\author{
P G (Scholar) ${ }^{1}$, Head of Department \& Professor $^{2}$,
}

Rognidan \& vikriti vidnyan, School of Ayurveda, Dr. D.Y Patil University,

Nerul, Navi Mumbai, Maharashtra, India

*Corresponding author: 8097267239, Email- dipashri.borse@ gmail.com

\section{ABSTRACT}

Thoughts and emotions triggered by stress can have an effect on stomach and bowel movement. Physical signs and symptoms of stress overload include chest pain, rapid heartbeat, loss of sexual drive, diarrhoea/ constipation. In this article we have tried to enlighten the association of stress and constipation. The mainly observed clinical features of Vibandha are Hard Stools, Excessive Straining, Sense of Incomplete Evacuation, Flatulence and Lower Abdominal Fullness. The stress hormone may contribute to constipation.

Keywords: stress and constipation (vibandha)

\section{INTRODUCTION}

The equilibrium of body and mind creates happiness while its imbalance causes the unhappiness i.e. Disease. Now days, stress and strains of Urbanization (Modern life styles), feeling of uncertainty and insecurity, fast running life, competition in every fields, poor hygiene are the main factors for malfunctioning of mind \& body.In this article, we have tried to enlighten some of the possible links between stress and constipation.

Constipation is a disease condition resembling

to Vibandha described in Ayurved. It refers to bowel movements that are infrequent or hard to pass and is a general term used to indicate fewer bowel movements, Solidified hard stools, painful defecation and feeling of bloating, abdominal discomfort or incomplete elimination. Constipation is a common cause of painful defecation.

Stress is defined as "a state of mental or emotional strain or tension resulting from adverse or demanding circumstances". The body reacts in a very unique way, as in such circumstances, the afflicted person may undergo severe diarrhea that completely disrupts the regularity of the sufferer's bowel movements, which would then be followed by a bout of constipation.

\section{Aspects of Stress and Constipation}

- Constipation occurs when the large intestine absorbs too much water from the stool with the result dry and hard stools are passed. It may also be due to inadequate 
contraction of bowel walls to expel the stool and waste product. It occurs due to Poor diet (low fiber diet). Less mobility and lack of exercise. Ageing, stress and travel. Ignoring the urge to defecate. Inadequate fluid intake are also the predisposing factors.

- Stress can also lead to constipation. When psychological stress leads to physical symptoms, they are known as somatic symptoms.

- The effects that stress hormones have on the body can cause constipation. In addition, when a person is stressed, they are more likely to eat an unhealthy diet, get less exercise or sleep, or forget to stay hydrated. These factors can lead to constipation.

- In stressful situations, the body's adrenal glands release a hormone called epinephrine, which plays a role in the so-called fight-or-flight response. It causes the body to divert blood flow from the intestines toward vital organs, such as the heart, lungs, and brain. As a result, intestinal movement slows down, and constipation can occur.

- While eating, the neurons that line digestive tract signal the intestines to contract and digest the food. When person is under stress, this digestive process can slow down to a crawl. If the stress is severe or long-term, symptoms such as stomach pain and constipation can become chronic.

- Stress can also cause inflammation to occur in gastrointestinal tract, increasing constipation and worsening existing inflammatory conditions.

- Age related aspect:Old age: Vibandha is caused by aggravated vata dosha in old age, along with decreased physiological functions of the body in old age constipation is caused due to increased medicinal intake such as NSAID'S, calcium channel blockers, anticholinergic drugs, calcium supplements, decreased intake of fluids and fibre in diet, metabolic factors, neurological diseases like Parkinson's disease, depression, stroke in old age results in decreased intestinal motility. Globally, prevalence of constipation in community dwelling elderly people is $50 \%$ and $74 \%$ in nursing home residents.

- Stress causes increased intestinal permeability. This permeability allows inflammatory compounds to come into the intestines, which can lead to a feeling of abdominal fullness - a common complaint among people who struggle with constipation.

- Under chronic stress, central nervous system will continuously interpret as being under constant physical threat and the continued slow movement in gut will translate into constipation becoming a chronic condition as well, causing physical and mental duress.

\section{DISCUSSION}

- Stress may affect normal healthy bacteria in the gut. Research has not confirmed this theory, but many people believe that stress may reduce the number of healthy gut bacteria in the body, thus slowing digestion.

- Ayurved states that these three layers can't exist without each other or we can say that these components are strongly dependent upon each other because body is the source for bonding and mind is for 
meditation to connect with the divine soul.

Management approaches Treating stress-related constipation some of the best ways to relieve constipation include

Preventive Aspects:

- Consumption of light and easily digestible high fiber diet.

- Intake of plenty of fluids and water (minimum 2-3 lt. per day)

- Practicing regular exercise.

- Lifestyle Management.

- Yogic Practices are beneficial in constipation.

- Alcohol, cigarettes, and foods high in sugar and fat can all increase the risk of constipation and stress. Avoiding or limiting these items may improve both symptoms.

\section{Curative Aspects:}

1,2 Basti Chikitsa: In Ayurveda, basti or medicated enema is considered as ardhchikitsa for vitiated vata dosha. Due to Basti there is shodhan of pakvashayastha mala \& sthanik dosha which leads to Shaman of Vata dosha. Basti stays at Pakwashaya and starts its action from there. Pakwashaya is the natural abode of Vayu. Basti conquers the vitiated Vata in its PrakrutaSthana by which Vata dwelling in other parts of the body is automatically conquered. Basti removes Malasanghata and thus maintains the Anulomagati of ApanaVayu. This further helps in regulation of Samana \&VyanaVayu. Vata is vitiated by Laghu, Ruksha, Sheeta etc.Gunas. AnuvasanaBasti (medicated oil Enema) with its Snigdha Guna destroys Rukshata, with Guru Guna, Laghuta and with Ushna Guna, Sheetata of Vata.

Shiro Basti: The word shiro means "head" and basti means "to retain" hence the process of retaining the medicated/herbal oil with the help of a leather cap over the shir pradesh (head region) is known as the shiro basti.
Identifying the sources of stress that may lead to constipation might be particularly helpful for people with a history of trauma or mental health conditions, such as depression or anxiety.

\section{CONCLUSION}

Stress can lead to constipation in several ways. Stress hormones directly influence bowel movements by affecting bodily processes. In addition, people are more likely to have a poor diet, drink too little water, and get less exercise when stressed, which can cause constipation. Anxiety and heightened emotions can cause or make constipation worse. A lifestyle based in harmony is a stress free lifestyle. Ayurveda applies its principles to both the mind and the body. Though the practices of meditation and yoga, Ayurveda helps a person expand their perception of themselves and how they relate to the world around them. While so many people are plagued with fear, anger, anxiety and / or depression, Ayurveda helps people to come to the realization that life can be and is beautiful.

\section{REFERENCES}

1. Charaka. Charaka SamhitaAgnivesha's treatise refined and annolated by Charaka redacted by Dridhabala with Ayurveda Deepika Commentary of Chakrapani Datta. Varanasi: Chaukambha Krishnadas Academy.

2. Agnivesha, Charaka Samhita with Charaka Chandrika Hindi Commentary by Dr. Brahmanand Tripathi, Part 2nd, Siddhisthana 1/30, 1st edn (reprint), Varanasi: Chaukhambha Krishnadas Academy;2009:p1166

3. Sahastrayogam,Dr.R.Nisteshwar;II nd Edition, 2008

4. Vagbhata,AstangaHridaya,Dr.Anna Moreshwar kunte , $8^{\text {th }}$ edition 
Chaukhambha Orientalia 2007, Varanasi

5. Sushruta

Samhita,Acharya Trikamji,Chaukhambha Orientalia, $8^{\text {th }}$ edition 2005, Varanasi.

6. Warner, Warners Clinical medicine Anxiety chapter.

7. journal Expert Review of Gastroenterology \& Hepatology

8. THE AMERICAN INSTITUTE OF STRESS

9. Drossman, D.A., 2006. Rome III: the new criteria. Chinese journal of digestive diseases, 7(4), pp.181185. Link

10. Roque, M.V. and Bouras, E.P., 2015. Epidemiology and management

constipation in

of chronic

patients. Clinical interventions in aging, 10, p.919. Link

11. Hsieh, C., 2005. Treatment of constipation in older adults. Am Fam Physician, 72(11), pp.227784. Link

12. Hosseinzadeh, S.T., Poorsaadati, S., Radkani, B. and Forootan, M., 2011. Psychological disorders in patients with chronic constipation. Gastroenterology and hepatology from bed to bench, 4(3), p.159. Link

Conflict of Interest: Non DOI: https://doi.org/10.52482/ayurline.v5i03.566 Source of funding:

Cite this article:

Stress and constipation (vibandha) - critical review

Dipashri Eknath Borse, Santosh Chavhan

Ayurline: International Journal of Research In Indian Medicine 2021; 5(4):01-04 